\title{
Ichthyofauna of the Sumidouro system, state of Minas Gerais, Brazil
}

\author{
Ruanny Casarim*, Débora Reis de Carvalho, Rafaela Bastos Pereira and Paulo Santos Pompeu \\ Universidade Federal de Lavras, Departamento de Biologia. Campus Universitário, s/n. CEP 37200-000. Lavras, Minas Gerais, Brazil. \\ * Corresponding author: E-mail: rucasarim@gmail.com
}

\begin{abstract}
Alterations in environmental conditions may cause changes to fish assemblages regarding their composition and distribution. This study aimed to describe the composition the ichthyofauna of the Sumidouro system and to compare it with the ichthyofauna found in the Lagoa Central. The Sumidouro system is a preserved aquatic biome located on the Rio das Velhas drainage on central Brazil while the Lagoa Central is an environment under anthropogenic impact located inside the Lagoa Santa city. Sampling of the Sumidouro system was carried out, in October 2012. The similarity of the fish assemblages of both systems was evaluated in four different scenarios, built from recently published data, and compared by a cluster analysis using Sorensen similarity index. The Sumidouro system is more similar to the historical fauna of the Lagoa Central or after its isolation from Rio das Velhas. This indicates that a cave located at this region (Sumidouro Cave) may act as a barrier to fish movements. The results also allow us to infer that the intensification of urbanization around the Sumidouro system may be causing loss of aquatic biodiversity, as observed in the Lagoa Central.
\end{abstract}

\section{INTRODUCTION}

Biological communities vary through time and space as a result of differences in habitat structure (Gorman and Karr 1978; Ferreira and Casatti 2006; Dubey et al. 2012). The recognition of mechanisms and factors responsible for such differences is one of the most important objectives of community ecology (Angermeier and Karr 1984; Sutherland et al. 2013).

There is a discussion regarding the importance of physical and biological factors as responsible for the distribution of freshwater fishes and some authors point that the spatial distribution of results from complex ecological relationships among species, which are influenced by environmental characteristics of the ecosystem, habitat connectivity (individual species turnover), and habitat availability, allied to species composition (Welcomme 1979; Werner 1986; Wootton 1998; Grenouillet and Hérissé 2004). Consequently, anthropogenic actions leading to habitat changes may have deep influence on species composition on ecosystems.

Currently, the fast expansion of urban centers has been causing alterations to aquatic environment through canalization, dams, siltation, and the reduction of vegetal cover (Malmqvist and Rundle 2002; Allan 2004; Casarim et al. 2012). Such activities directly affect the geomorphology of the channel, leading to changes in the original lotic characteristics, and causing the loss of biodiversity and a decrease in the abundance of fishes (Sale 1985; Pompeu et al. 2005; Cunico et al. 2006). Another frequently observed problem in intensively inhabited areas is the modification of the community structure due to the introduction of exotic species in the watercourse.

The non-native species with invasive potential adapt to the environment in which they are introduced due to their facility to reproduce and disperse, they may preclude the habitat use by native species (Zaret and Paine 1973; Welcomme 1988; Canonico et al. 2005; Vitule 2009), leading to local extinction (Welcomme 1988). Since most invasive exotic species do not have natural predators where they are introduced, they may proliferate fast, thus competing with, or even feeding directly on, native species (Agostinho et al. 2007).

Comparative studies of lagoons that involve substantial variations of abiotic conditions are excellent opportunities to examine the effects of factors responsible for structuring fish assemblages (Tejerina-Garro et al. 1998). The aim of this study is to describe the composition of the ichthyofauna in the Sumidouro system, a preserved environment located at the protected area of Parque Estadual do Sumidouro (Minas Gerais state, Brazil). Also, this study aim to characterize the ichthyofauna of the Sumidouro system and compare it with the fauna of the Lagoa Central of the Lagoa Santa city, located in the same basin, and which has been suffering several environmental impacts.

\section{MAterials ANd Methods Study area}

This study was developed in the Sumidouro system, comprising Sumidouro lagoon and Samambaia stream. Studied areas are located at $19^{\circ} 32^{\prime}$ S and $43^{\circ} 56^{\prime} \mathrm{W}$, in Parque Estadual do Sumidouro, Rio das Velhas basin (Figure 1). The park is $50 \mathrm{Km}$ from Belo Horizonte, in municipalities of Lagoa Santa and Pedro Leopoldo, state of Minas Gerais, central Brazil. The Parque Estadual do Sumidouro consists of a Federal Conservation Unit and belongs to the category 'sustainable use of natural resources' - APA Carste de Lagoa Santa. Such conservation units aim to promote the conservation of nature through the sustainable use of part of available resources (MMA 2000). 
The Sumidouro lagoon is a temporary lake that has multiannual cycles. The lagoon may achieve a perimeter of $15 \mathrm{Km}$ when full, or be completely devoid of water in drought periods (Figure 2A and 2B). This drought and flood cycle is a natural phenomenon. The lagoon lies in a karstic region, a type of relief formed by the corrosive effect of water on soluble rocks such as limestone (IEFMG 2010). Due to the peculiar characteristics of this region many phenomena of karstic hydrography, such as upwellings and sinkholes, are present at the Parque Estadual do Sumidouro. There are sinkholes within the Sumidouro lagoon, which gave the place its name (IEF-MG 2010). The water from the Samambaia stream is the main water source of the lagoon, flowing into these sinkholes and then rising, debouching into the Rio das Velhas (IEFMG 2010; Pereira and Caldeira 2011).

The Lagoa Central is located downtown in the municipality of Lagoa Santa, $19^{\circ} 38^{\prime} \mathrm{S}$ and $43^{\circ} 53^{\prime} \mathrm{W}$, $40 \mathrm{~km}$ north of Belo Horizonte, and is part of the Rio das Velhas basin, Brazil (Pompeu and Alves 2003). The lagoon is relatively shallow (depth ${ }_{\text {max. }}=7 \mathrm{~m}$ ), situated at an altitude of $740 \mathrm{~m}$, covering a total area of $1.31 \mathrm{~km}^{2}$ and with a drainage basin of $11.34 \mathrm{~km}^{2}$ (Parizzi et al. 1998). The Lagoa Central was considered an ecosystem with high diversity of aquatic life, excellent water quality and great transparency. However, since the end of the 1970s, the region has suffered increasing transformations as a consequence of disordered urbanization (Coutinho and Barbosa 1986). Such increase in human occupation not only caused changes in the water quality and transparency, but also in its communication with Rio das Velhas through the Bebedouro stream. Furthermore, studies show a decrease in biological diversity due to the introduction of exotic fish species (Pompeu and Alves 2003).

\section{Data collection}

Twenty-three points were sampled once in the Samambaia stream, in October 2012 (Figure 3). At each point, two trawl nets were used to isolate a stretch of six meters with the aim of collecting the ichthyofauna. Fish collections were performed from downstream to upstream with sieves made from mosquito netting $(80 \mathrm{~cm}$ in diameter, $1 \mathrm{~mm}$ mesh size) and with trawl nets ( $3 \mathrm{~m}$ long, $5 \mathrm{~mm}$ mesh size). For each point, $20 \mathrm{~min}$ was established as standard time for sampling.

The Sumidouro lagoon was also sampled once in October 2012 (Figure 3). For fish collections, trawl nets were used ( $3 \mathrm{~m}$ long, $50 \mathrm{~mm}$ mesh size) and two sets of gillnets with 2.4 - 14 centimeters-mesh between opposite knots and 10 meters long. Each set had approximately $150 \mathrm{~m}^{2}$. A total of ten drags were performed at 6:00 $\mathrm{h}$ and 18:00 h with gillnets; these were set up in the afternoon and removed the following morning, giving a total of $12 \mathrm{~h}$ of sampling. Specimens of each species were deposited in the Ichthyological Collection of the Federal University of Lavras (UFLA). Fish were collected under the IEF license \#UC127/12.

Fishes from the Sumidouro system (Sumid) were compared with those from the Lagoa Central of the Lagoa Santa city. Because Lagoa Central has been submitted to different human impacts, including isolation from the main river, we considered the Lagoa Central (LC) fish fauna in four different scenarios based on Pompeu and Alves (2003): historical fauna (LC-Hist: 17 species); current fauna (LC-Curr: 10 species, including exotic ones); historical fauna minus lost species (migratory) due to the current interruption of communication with Rio das Velhas (LC-Isol: 14 species); and current fauna minus lost species (others) by introduction of exotic species (LC-Exot: 6 species). In the last scenario, we considered lost due to the exotic fish introduction all the lost species that do not depend on the communication between the lake and the river to complete their life cycle. These four scenarios and the fishes from the Sumidouro system were compared through a Cluster analysis based on the similarity index of Sorensen, UPGMA grouping (Davis and Greenes 1983). Identification of the sampled fishes in the Sumidouro system was based on Britski et al. (1988).

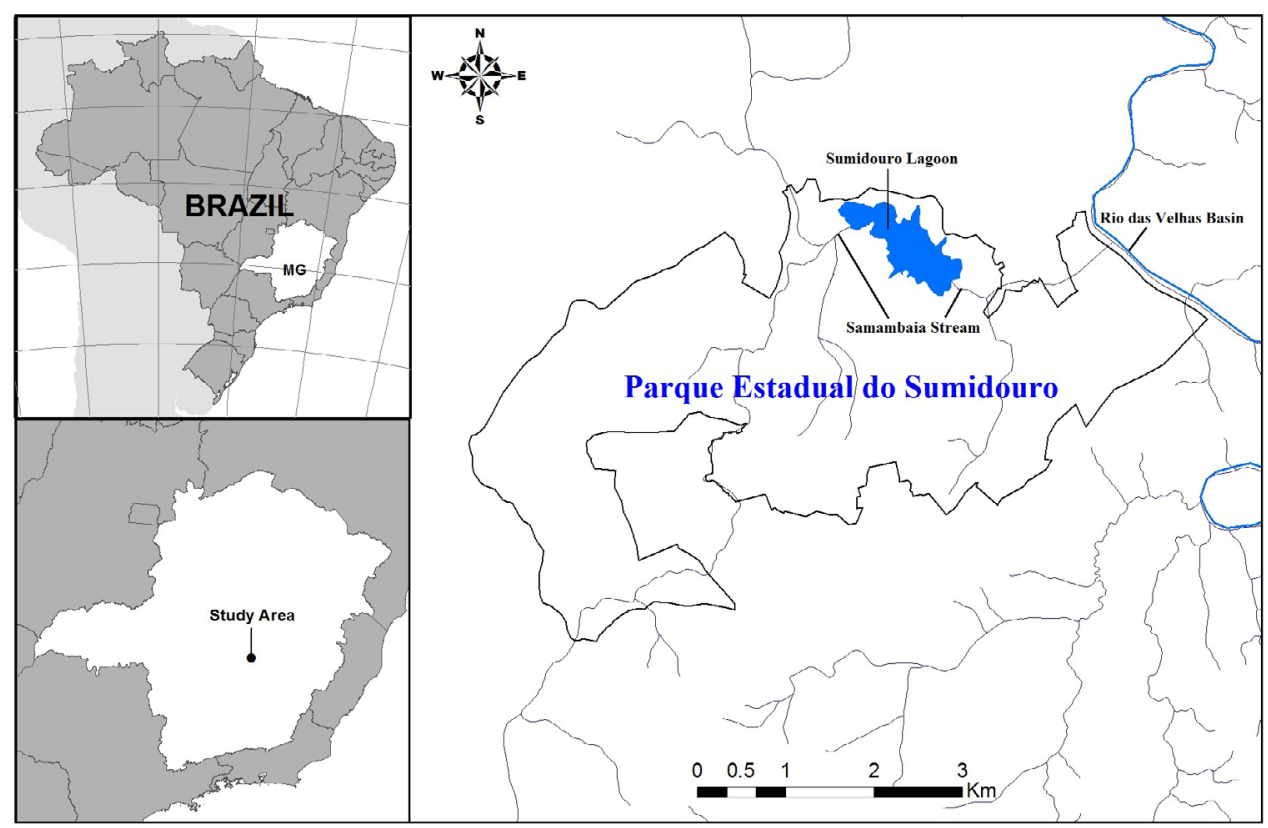

FIGURE 1. Location map of the Sumidouro System highlighting the Sumidouro Lagoon, Samambaia stream and the sample sites. 
FIGURE 2. The Sumidouro lagoon when full (A) and completely devoid of water (B) in October 2012 and July 2013, respectively (Photos Ruanny Casarim and Parque Estadual do Sumidouro-IEF)

\section{RESULTS}

Overall, 16021 fish specimens, belonging to five orders, nine families, 12 genera and 16 species, were collected in the Sumidouro lagoon and Samambaia stream, which, at least two of these species are exotic to the Rio das Velhas basin: Tilapia rendalli and Hoplosternum littorale (Table 1) (Godinho and Godinho 2003). The greatest biodiversity was found in the Characiformes (68\%) and Siluriformes $(25 \%)$ orders.

Ten species were known for the Lagoa Central (Pompeu and Alves 2003). By adding nine species found in the present study, 19 species are identified for the karstic system of this region.

When comparing the fishes of the Sumidouro system with the different scenarios built for the Lagoa Central, greater similarity was found with the historical fauna of the Lagoa Central (LC-Hist), or after its isolation from the Rio das Velhas (LC-Isol) (53\%) (Figure 4). Both systems share originally five small sized characins (A. lacustris, $A$. taeniatus, $H$. nana, $H$ sanctae and $C$. zebra), a native predator (H. malabaricus), two catfishes (R. quelen and T. galeatus) and $G$. carapo. However, migratory species with historical occurrence in the Lagoa Central ( $L$. reinhardti, P. costatus and $P$. maculatus), which were lost due to interruption of communication with Rio das Velhas, were not found in the Sumidouro system. Only $35 \%$ of the similarity was founded between the studied system with the current fauna (LCCurr) and after introduction of exotic species (LC-Exot) of the Lagoa Central.

\section{Discussion}

The greatest richness found in the region is represented by the order Characiformes, a pattern widely known for South America (Lowe-Mcconnell 1987). The order Characiformes is one of the largest groups of freshwater fishes, with species found both in lentic and lotic systems (Buckup et al. 2000; Nelson 2006). However, the order Siluriformes was more frequent in the studied stream than in the lagoon. Species of this order may present small or large size and are found mainly in fast flowing habitats, river bottoms and among rocks and vegetation (Britski 1981). Among the added species, only two were found in the lagoon, and the other seven were found in stream, indicating that most of the unknown fauna is found in small water courses (Casarim et al. 2012).
The greater similarity between the historical fauna of the Lagoa Central of the Lagoa Santa city and the Sumidouro system may be explained by the obstruction of the natural communication between Lagoa Central and the rio das Velhas, formerly provided by the Bebedouro stream. This obstruction caused the isolation of the Lagoa Central and the extinction of some fish species characteristics of the stream (Pompeu and Alves 2003). At the Sumidouro system some of these stream fish species are still present (Characidium zebra and Trachelyopterus galeatus). In addition, the similarity found between the fish fauna from the Lagoa Central after its isolation from the Rio das Velhas and the Sumidouro system may be explained by the fact that the Lagoa Central isolation also caused the extinction of the migratory fish species, such as Prochilodus costatus and Pimelodus maculatus (Pompeu and Alves 2003). Besides, the greater similarity of this situation with Sumidouro system may be explained by the fact that this karstic system is naturally isolated, since the whole system flows to the Sumidouro Cave, continuing his drainage underground. In fact, any migratory species were recorded in this study.

Despite the fact, that the Sumidouro lagoon and the Samambaia stream are in an environmental protection area (APA - Área de Proteção Ambiental), both suffer with problems related to urbanization such as the non-native species presence. The species introduction is one of the main problems for freshwater fish conservation (Cowx 2002; Cambray 2003; Collares-Pereira and Cowx 2004). Invasive species generally reduce native inland water species abundance through predation, hybridization, parasitism or competition (Canonico et al. 2005). Even before the creation of the Parque Estadual do Sumidouro, the lake was indiscriminately used by predatory tourism and urbanization of the margins facing, as a consequence, water contamination (Pereira and Caldeira 2011) and colonization by exotic species. Anthropic actions in the region, which are still constant, have contributed to the deterioration of water, vegetation and relief (IEF- MG 2010). The comparison between the two systems made in this study allows one to infer that the intensification of urbanization around the Sumidouro system may cause the significant loss of richness of fish, as had already occurred with the Lagoa Central, especially if new exotic species are introduced. 
TABLE 1. Fish species collected in Rio das Velhas basin, per sampled environment, Sumidouro Lagoon, Samambaia stream, Historical and Current Lagoa Santa Lagoon (CI-UFLA = number of species deposited in the Ichthyological Collection of UFLA, *Exotic species, $\theta$ Fishes with migratory behavior). Valid names according to Eigenmann (1918), Buckup (1992), Mago-Leccia (1994), Britski (2001), Godinho and Godinho (2003).

\begin{tabular}{|c|c|c|c|c|}
\hline \multirow{2}{*}{ TAXON } & \multirow{2}{*}{ SUMIDOURO LAGOON } & \multirow{2}{*}{ SAMAMBAIA STREAM } & \multicolumn{2}{|c|}{ LAGOA CENTRAL } \\
\hline & & & Hist. & Current \\
\hline \multicolumn{5}{|l|}{ CHARACIFORMES } \\
\hline \multicolumn{5}{|l|}{ Acestrorhynchidae } \\
\hline Acestrorhynchus lacustris (Lütken,1875) & & & $\mathrm{X}$ & \\
\hline \multicolumn{5}{|l|}{ Anostomidae } \\
\hline Leporinus reinhardti ${ }^{\theta}$ Lütken,1875 & & & $\mathrm{X}$ & \\
\hline \multicolumn{5}{|l|}{ Characidae } \\
\hline Astyanax aff. eigenmanniorum (Cope,1894) & CI-UFLA 0730 & & & \\
\hline Astyanax lacustres (Lütken,1875) & CI-UFLA 0719 & CI-UFLA 0719 & $\mathrm{X}$ & $\mathrm{X}$ \\
\hline Astyanax rivularis (Lütken,1875) & & CI-UFLA 0720 & $\mathrm{X}$ & \\
\hline Astyanax taeniatus (Jenyns, 1842) & CI-UFLA 0718 & CI-UFLA 0718 & & \\
\hline Hasemania nana (Lütken,1875) & CI-UFLA 0717 & CI-UFLA 0717 & $\mathrm{X}$ & \\
\hline Hyphessobrycon gracilis (Lütken,1875) & & & $\mathrm{X}$ & \\
\hline Hyphessobrycon santae (Eigenmann, 1907) & CI-UFLA 0716 & CI-UFLA 0716 & $\mathrm{X}$ & \\
\hline Serrasalmus brandtii Lütken,1875 & & & $\mathrm{X}$ & \\
\hline \multicolumn{5}{|l|}{ Crenuchidae } \\
\hline Characidium zebra Eigenmann, 1909 & & CI-UFLA 0722 & $\mathrm{X}$ & \\
\hline Characidium lagosantensis Travassos, 1947 & & & $\mathrm{X}$ & \\
\hline \multicolumn{5}{|l|}{ Erythrinidae } \\
\hline Hoplias malabaricus (Bloch, 1794) & CI-UFLA 0724 & CI-UFLA 0724 & $\mathrm{X}$ & $\mathrm{X}$ \\
\hline Hoplias intermedius (Günther, 1864) & CI-UFLA 0731 & & & $\mathrm{X}$ \\
\hline \multicolumn{5}{|l|}{ CYPRINODONTIFORMES } \\
\hline \multicolumn{5}{|l|}{ Poeciliidae } \\
\hline Pamphorichthys hollandi (Henn, 1916) & & & & $\mathrm{X}$ \\
\hline
\end{tabular}

Poecilia reticulata Peters, 1859

CI-UFLA 0727

\section{Prochilodontidae}

Prochilodus $\operatorname{costatus}^{\ominus}$ Valenciennes 1850

$\mathrm{X}$

Tetragonopterinae

Serrapinnus heterodon (Eigenmann, 1915)

\section{GYMNOTIFORMES}

\section{Gymnotidae}

Gymnotus carapo Linnaeus, 1758

CI-UFLA 0725

$\mathrm{X}$

\section{PERCIFORMES}

\section{Cichlidae}

Cichla cf. monoculus* Agassiz, 1831

Tilapia rendalli* (Boulenger 1877)

\section{SILURIFORMES}

Auchenipteridae

Trachelyopterus galeatus (Linnaeus,1766)

Callichthyidae

Hoplosternum littorale* (Hancock, 1828)

Heptapteridae

Pimelodella lateristriga (Lichtenstein, 1823)

Rhamdia quelen (Quoy and Gaimard, 1824)

CI-UFLA 0721

CI-UFLA 0721

Pimelododidae

Pimelodus maculatus ${ }^{\theta}$ Lacépède, 1803

CI-UFLA 0729

$\mathrm{X}$

Sternopygidae

Eigenmannia microstoma (Reinhardt, 1852)

\section{$\mathrm{X}$}

$\mathrm{X} \quad \mathrm{X}$




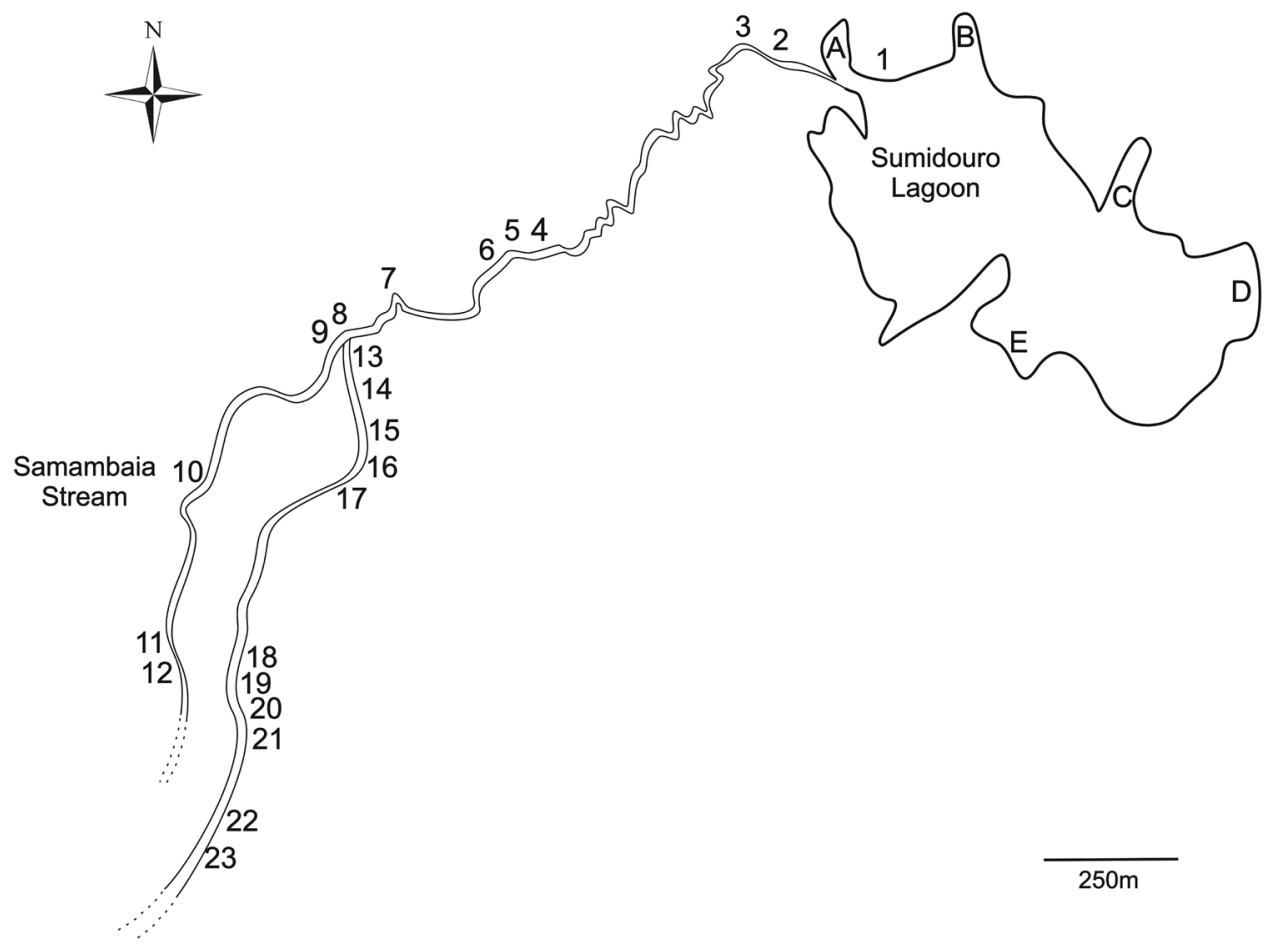

FIGURE 3. Scheme of study points, Sumidouro Lagoon (A - E) and Samambaia stream (1-23), located in the Parque Estadual do Sumidouro, Minas Gerais, Brazil.

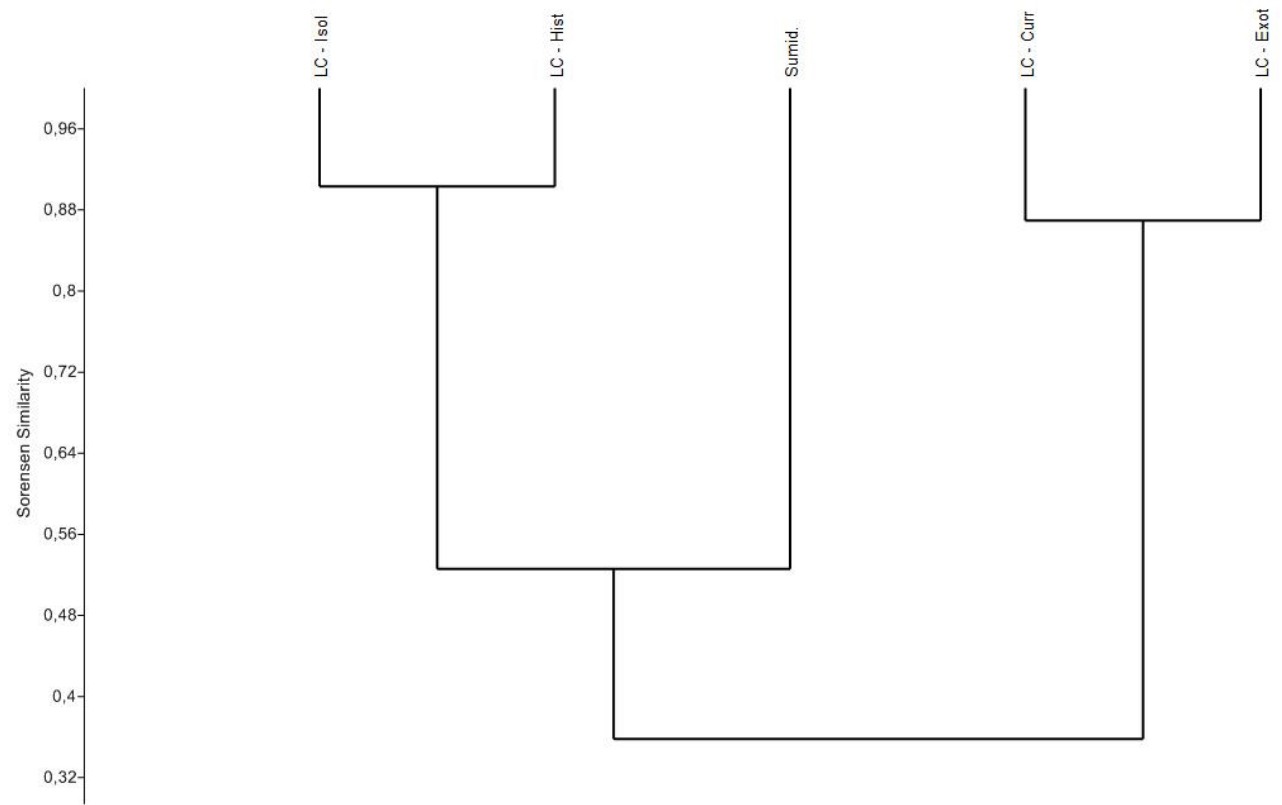

FIGURE 4. Percentage of similarity of the historical (LC - Hist) and current fauna (LC - Curr), presence of exotic species (LC - Exot) and the scenario after isolation of the Lagoa Santa (LC - Isol) in relation to the fishes found in the Sumidouro system (Sumid.).

ACKNOWLEDGMENTS: We thank the Graduate program in Applied Ecology of UFLA and Parque Estadual do Sumidouro for providing logistic support. We also thank Polyanne Aguiar for drawing the map. Authors received financial support from CNPq (Conselho Nacional de Desenvolvimento Científico e Tecnológico) and CAPES (Coordenação de Aperfeiçoamento de Pessoal de Nível Superior).

\section{Literature Cited}

Agostinho, A.A., L.C. Gomes and F.M. Pelicice. 2007. Ecologia e manejo de recursos pesqueiros em reservatórios do Brasil. EDUEM: Maringá. 501 pp.

Allan, J. D. 2004. Landscapes and Riverscapes: The influence of land use on Stream Ecosystems. Annual Review of Ecology, Evolution, and Systematics. 35: 257-84 (doi: 10.1146/annurev. ecolsys.35.120202.110122).

Angermeier, P.L.and J.R. Karr. 1984. Fish communities along environmental gradients in a system of tropical streams. Environmental Biology of
Fishes 9: 117-135 (doi: 10.1007/BF00690857).

Britski, H.A. 1981. Peixes de água doce; pp. 84-93, in: J.C.M. Carvalho. Atlas da fauna brasileira. São Paulo: Melhoramentos.

Britski, H.A., Y. Sato and A.B.S. Rosa. 1988. Manual de identificação de peixes da região de Três Marias: Com chaves de identificação para os peixes da bacia do São Francisco. Brasília: Câmara dos Deputados/ Codevasf. 115 pp.

Britski, H.A. 2001. Sobre a obra Velhas-Flodens Fiske [Peixes do rio das Velhas], pp. 15-22, in: C.B.M. Alves and P.S. Pompeu. (ed.). Peixes do rio das Velhas: Passado e presente. Belo Horizonte: SEGRAC.

Buckup, P.A. 1992. Redescription of Characidium fasciatum, type species of the Characidiinae (Teleostei, Characiformes). Copeia 1992: 10661073 (doi: 10.2307/1446639).

Buckup, P.A., C. Zamprogno, F. Vieira and R.L. Teixeira. 2000. Waterfall climbing in Characidium (Crenuchidae: Characidiinae) from eastern Brazil. Icththyological Explorations Freshwaters 11(3): 273-278 (http://www.academia.edu/1831320/Waterfall_climbing_in_ 
Characidium_Crenuchidae_Characidiinae_from_eastern_Brazil).

Canonico, G.C., A. Arthington, J.K. McCrary and M.L. Thieme. 2005. The effects of introduced tilapias on native biodiversity. Aquatic Conservation: Marine and Freshwater Ecosystem 15: 463-483 (doi: 10.1002/aqc.699).

Cambray, J.A. 2003. The need for research and monitoring on the impacts of translocated sharptooth catfish, Clarias gariepinus, in South Africa. African Journal of Aquatic Science 28: 191-195 (doi: 10.2989/16085910309503786).

Casarim, R., M.L. Bueno and P.S. Pompeu. 2012. Ichthyofauna of the Aiuruoca River basin, Minas Gerais, Brazil. Check List 8(6): 11661171 (http://www.checklist.org.br/getpdf?SL020-12).

Collares-Pereira, M.J. and I.G. Cowx. 2004. The role of catchment scale environmental management in freshwater fish conservation. Fisheries Management and Ecology 11: 303-312 (doi: 10.1111/j.13652400.2004.00392.x).

Coutinho, M.E. and F.A.R. Barbosa. 1986. Distribuição vertical de matéria orgânica, nitrogênio orgânico total, fósforo total e algumas formas iônicas dos sedimentos recentes de 3 Lagos de Minas Gerais. Acta Limnologica Brasiliensia 1: 401-429 (http://ecologia.icb.ufmg. br/ rpcoelho/SBL_Diretoria/Acervo_Acta/acta_limnologica_ contents1E_files/Art.19\%20Vol\%20I.pdf).

Cowx, I.G. 2002. Analysis of threats to freshwater fish conservation: Past and present challenges; pp. 201-220, in: Collares-Pereira, M.J., I.G. Cowx and M.M. Coelho (ed.). Conservation of Freshwater Fishes: Options for the Future. Oxford: Blackwell Science.

Cunico, A.M., A.A. Agostinho and J.D. Latini. 2006. Influência da urbanização sobre as assembleias de peixes em três córregos urbanos de Maringá-Paraná. Revista Brasileira de Zoologia 23(4): 1101-1110 (doi: 10.1590/S0101-81752006000400018).

Davis, B.M. and K.A. Greenes. 1983. Estimation using Spatially distributed multivariate data: an example with coal quality: math. Geology 15: 287-300 (doi: 10.1007/bf01036071).

Dubey, V.K., U.K. Sarkar, A. Pandey, R. Sani and W.S. Lakra. 2012. The influence of habitat on the spatial variation in fish assemblage composition in an unimpacted tropical River of Ganga basin, India. Aquatic Ecology 46: 165-174 (doi: 10.1007/s10452-012-9389-9).

Eigenmann, C.H. 1918. The American Characidae [Part 2]. Memoirs of the Museum of Comparative Zoology 43(2): 103-208 (http:// biodiversitylibrary.org/page/4372811).

Ferreira, C.P. and L. Casatti. 2006. Influência da estrutura do hábitat sobre a ictiofauna de um richo em uma micro-bacia de pastagem, São Paulo, Brasil. Revista Brasileira de Zoologia 23(3): 642-651 (doi: 10.1590/ S0101-81752006000300006).

Godinho, H. P. and A.L. Godinho. 2003. Águas, peixes e pescadores do São Francisco das Minas Gerais. Belo Horizonte: PUC Minas. 458 pp.

Gorman, O.T. and J.R. Karr. 1978. Habitat structure and stream fish communities. Ecology 59(3): 507-515 (doi: 10.2307/1936581).

Grenouillet, G., D. Pont and C. Hérissé. 2004. Within-basin fish assemblage structure: the relative influence of habitat versus stream spatial position on local species richness. Canadian Journal of Fisheries and Aquatic Sciences 61: 93-102 (doi: 10.1139/f03-145).

IEF-MG. 2010. Plano de Manejo do Parque Estadual do Sumidouro. Lagoa Santa: Contextualização da unidade de conservação. 52 pp.

Lowe-McConnell, R.L. 1987. Ecological Studies in Tropical Fish Communities. London: Cambridge University Press. 382 pp.

Mago-Leccia, F. 1994. Electric fishes of the continental waters of America. Caracas: Biblioteca de la Academia de Ciencias Fisicas, Matematicas e Naturales. 206 pp.

Malmqvist, A. and S. Rundle. 2002. Threats to the running water ecosystems of the world. Environmental Conservation 29(2): 134-
153 (doi: 10.1017/S0376892902000097).

MMA-Ministério do Meio Ambiente. 2000. Lei no 9.985, de 18 de julho de 2000. Regulamenta o artigo 225, § $1^{\circ}$, incisos I, II, III e VII da Constituição Federal, institui o Sistema Nacional de Unidades de Conservação da Natureza e dá outras providências. Accessible at http://www.mma.gov.br/estruturas/250/_publicacao/250_ publicacao30082011035301.pdf. Captured on 21 November 2012.

Nelson, J.S. 2006. Fishes of the World. 4th edition. New York: John Wiley and Sons, Inc. 601 pp.

Parizzi, M.G., M.L. Salgado-Labouriau and H.C. Kohler. 1998. Genesis and environmental history of Lagoa Santa, southeastern Brazil. The Holocene 8: 311-321 (doi: 10.1191/095968398670195708).

Pereira, G. and R.B.A. Caldeira. 2011. Impactos antrópicos no patrimônio natural e cultural do Vetor Norte da Região Metropolitana de Belo Horizonte (RMBH). Revista de Biologia e Ciências da Terra 11(1): 2231 (http://eduep.uepb.edu.br/rbct/sumarios/pdf/Artigo_BioTerra_ V11_N1_2011_03.pdf).

Pompeu, P.S. and C.B.M. Alves. 2003. Local fish extinction in a small tropical lake in Brazil. Neotropropical Ichthyology 1: 133-135 (doi: 10.1590/S1679-62252003000200008).

Pompeu, P.S., M. Callisto and C.B.M. Alves. 2005. The effects of urbanization on biodiversity and water quality in the Rio das Velhas basin, Brazil. American Fisheries Society Symposium 47: 11-22 (http://www.icb. ufmg.br/labs/benthos/index_arquivos/pdfs_pagina/Pompeu.etal2005.pdf).

Sale, M.J. 1985. Aquatic ecosystem response to flow modification: an overview of the issues; pp. 25-31, in: F.W. Olson (ed.). Proceedings of the Symposium on Small Hydropower and Fisheries. Bethesda: American Fisheries Society.

Sutherland, W.J., R.P Freckleton, H.C.J. Godfray, S.R. Beissinger, T. Benton, D.D. Cameron, Y. Carmel et al. 2013. Identification of 100 fundamental ecological questions. Journal of Ecology 101: 58-67 (doi: 10.1111/1365-2745.12025).

Tejerina-Garro, F.L., R. Fortin and M.A. Rodríguez. 1998. Fish community structure in relation to environmental variation in floodplain lakes of the Araguaia River, Amazon Basin. Environmental Biology of Fishes 51: 399-410 (doi: 10.1023/A:1007401714671).

Welcomme, R.L. 1979. Fisheries Ecology of Floodplains Rivers. London: Longman. 317 pp.

Welcomme, R.L. 1988. International Introductions of Inland Aquatic Species. FAO Fisheries Technical Paper. Rome: Food and Agriculture Organization of the United Nations. $318 \mathrm{pp}$.

Werner, E.E. 1986. Species interactions in freshwater fish communities; pp. 344-358, in: J. Diamond and T.J Case (ed.). Community Ecology. New York: Harper and How.

Wootton, R.J. 1998. Ecology of Teleost Fishes. $2^{\text {nd }}$ edition. London: Chapman and Hall. 392 pp.

Vitule, J.R.S. 2009. Introdução de peixes em ecossistemas continentais brasileiros: revisão, comentários e sugestões de ações contra o inimigo quase invisível. Neotropical Biology and Conservation 4(2): 111-122 (doi: 10.4013/nbc.2009.42.07).

Zaret, T. M. and R.T. Paine. 1973. Species introduction in a tropical Lake: A newly introduced piscivore can produce population changes in a wide range of trophic levels. Science 182: 449-445 (doi: 10.1126/ science.182.4111.449).

RECEIVED: October 2013

ACCEPTED: May 2014

Published ONLINE: September 2014

EDITORIAL RESPonsibility: Pedro Hollanda Carvalho 